\title{
Anthrovision
}

Vaneasa Online Journal

Vol. $7.1 \mid 2019$

Aesthetic Encounters

\section{Dak'Art Off. Between Local Art Forms and Global Art Canon Discourses.}

\section{Thomas Fillitz}

\section{(2) OpenEdition \\ 1 Journals}

\section{Electronic version}

URL: http://journals.openedition.org/anthrovision/4841

DOI: 10.4000/anthrovision.4841

ISSN: 2198-6754

\section{Publisher}

VANEASA - Visual Anthropology Network of European Association of Social Anthropologists

\section{Electronic reference}

Thomas Fillitz, « Dak'Art Off. Between Local Art Forms and Global Art Canon Discourses. », Anthrovision [Online], Vol. 7.1 | 2019, Online since 11 March 2020, connection on 13 November 2020. URL : http://journals.openedition.org/anthrovision/4841; DOI : https://doi.org/10.4000/anthrovision. 4841

This text was automatically generated on 13 November 2020.

(c) Anthrovision 


\title{
Dak'Art Off. Between Local Art Forms and Global Art Canon Discourses.
}

\author{
Thomas Fillitz
}

\section{Introduction}

1 There is an undisputed thesis among art specialists that art biennials are global in their perspective, displaying artists from the whole world beyond any national or transnational loyalties. This global dimension expresses a thrive for multitude in two perspectives: (a) in a geospatial and temporal one, it brings together within one cultural space artists and their artworks from different regions of the world and a plurality of modernities; (b) instead of one clearly defined art form, art itself encompasses various categories. This assumption is based on the conceptualization of a plurality of regional art histories, characterized by antinomies of art, and clearly rejecting any overall validity of the occidental art historical narrative, i.e. of one dominant global art canon.

Yet, experts like Ute Meta-Bauer, Terry Smith, or Peter Osborne, express a present-day 'biennial fatigue.' This concerns, first, the huge number of art biennials which overlap in time, making it impossible to visit all of them. Second, and more importantly, Terry Smith (2012) sees this 'fatigue' as resulting from an 'overproduction': 'Since 2000 the biennial has been widely seen as being in a crisis of overproduction, of having become stale in form (theme A, subthemes a,b,c,d, x number of artists, y numbers of works each, in $\mathrm{z}$ amount of rooms ... )' (ibid.: 92-3). Or, according to Jan Verwoert (2010), the artworks and the way of their interconnected display within the exhibition's space 'seem to have by now become so recognizable that (...) these works can casually be referred to in terms of a genre: "biennial art"' (186-7, italics by the author). Generically, this art corresponds to the aforementioned two characteristics of multitude, adding 
characteristic (c) that art practices favour social contexts, the shift into art's heteronomy, in Jacques Rancière's vocabulary (2001).

3 This latter notion refers to several transformations of the characteristics of contemporary art: (a) geo-cultural multitude is connected to core groups of artists that highly renowned globally acting curators are favouring; (b) the 'trans-categoriality' (Osborne 2013) of art forms shifts into other dominant forms, installation art (Groys 2008), and participatory art (Papastergiadis 2008); (c) this shift is connected to a transfer of artworks away from the field of art's autonomy towards the one of its heteronomy - that is its embedment within socio-cultural contexts. As Boris Groys (2008) highlights for installations, artists take up images and objects from everyday life and work with them in the field of art. Regarding participatory art, Nikos Papastergiadis (2008) elaborates the various aspects of the artistic process which consists in selecting a group of people, and focusing on the quality of social relations which emerge during the artistic process.

4 Thus another encompassing global art canon seems to re-emerge - now not as narrative of occidental art history, but as a dominant narrative that is based on internationally most renowned biennial exhibitions. This discourse indeed is the product of superstar curators who have specialized on these mega-events, such as Okwui Enwezor, Hou Hanru, Charles Esche, Carolyn Christov-Bakargiev, and Catherine David.

5 The production of such a global contemporary art canon, however, is in sharp contrast to the widely acknowledged concept of the global plurality of art worlds (as art historical concept) and their antinomies (different histories), and not of the global art world.

Dak'Art, Ancient Palais de Justice

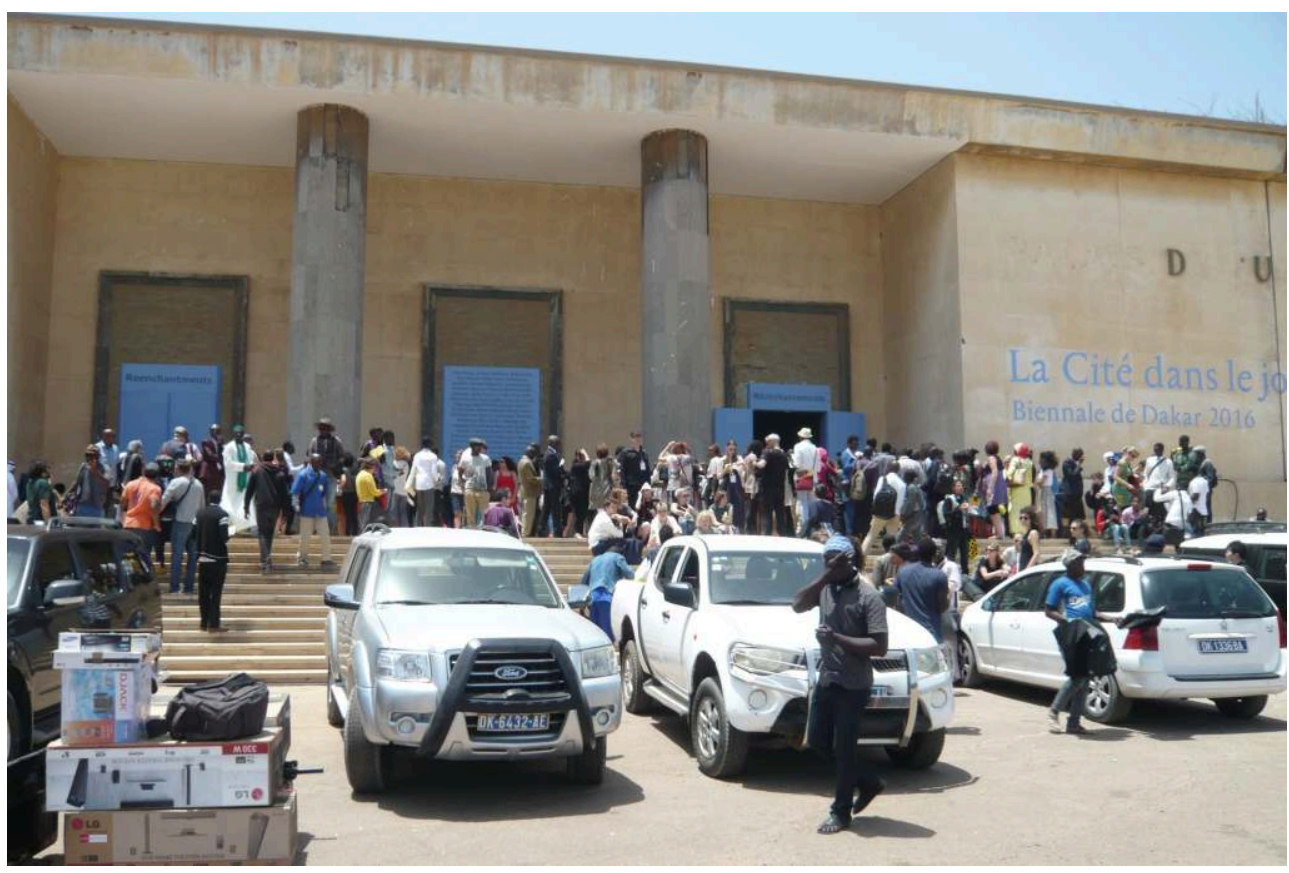

Photograph by Thomas Fillitz. 
Based on my research on the Biennale of Contemporary African Art in Dakar, Dak'Art, I intend to reflect this idea of an overall production of a new global contemporary art canon. In particular, Senegalese artists initiated exhibitions of their newest achievements during the Biennale time. From 2002 on all these activities have been labelled as Dak'Art Off, and this field became most successful with over 250 individual or group exhibitions these days.

\section{An Off site}

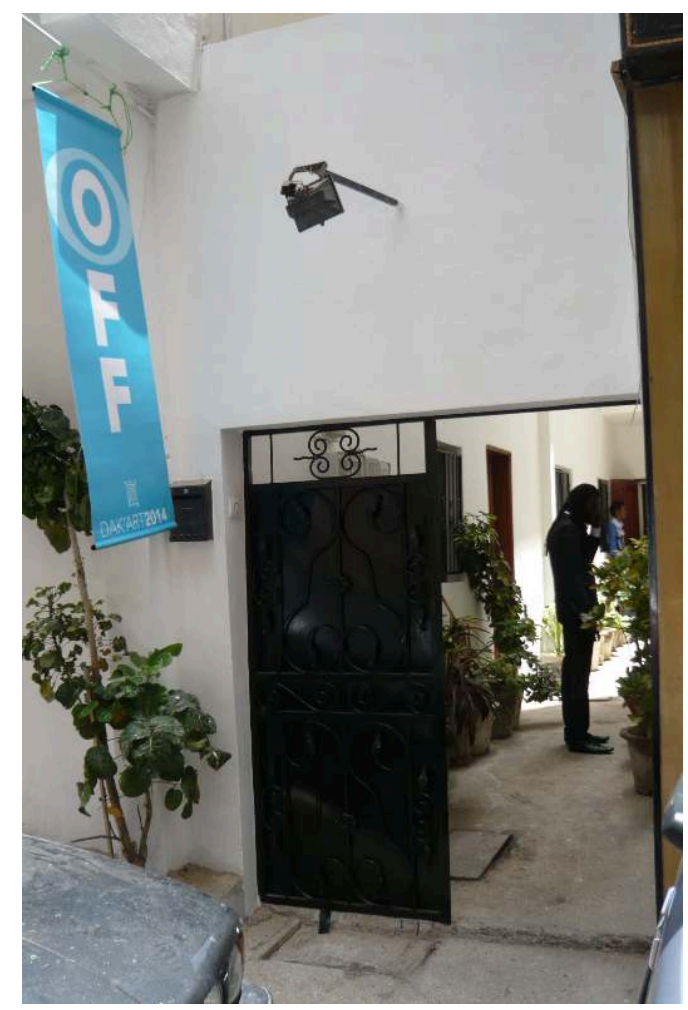

Dak'Art Off 2014

Photograph by Thomas Fillitz.

7 As artists clearly view the Off in opposition to the Biennale central venue, the Exposition internationale, this space offers valuable insights for reflecting on the influence of international trends on local artistic practices. I shall argue that an understanding of the artworks in the off requires above all insights into the history of modern and contemporary art of the Dakar art world, whereas the Biennale's selections are more informed by the global discourses which constitute the contexts of the curatorial teams.

8 After introducing the major differences between the Biennale and the Off, I shall deal in the second part with the dominance of painting, which appears as a longue durée, however re-defined periodically. A striking feature of Senegal's history of modern art is that breaks and new trajectories in the arts often coincide with social, economic, and political constellations. The third part connects the question about the production of another global art canon to local artistic practices. The example of the off allows a review of another aspect of global discourses, the criterion of contemporary art's insertion into society. The expression of socio-cultural aspirations has been an overall objective of dakarois artists since independence in 1960. It stretches from artists as 
central agents in the creation of a national cultural discourse to a conceptualization of art at the service of the local population. This relates to questioning what art can contribute to a critical public discourse, and by means of which pictures local neighbourhoods can be reached.

\section{Installation Art at Dak'Art and Art Forms at the Off}

9 As mega-art event that is devoted to African artists and artists of its Diaspora, this Bienniale started in 1996. Senegalese artists soon became disappointed with selection practices, as they had lobbied among politicians for an international biennial format during the 1980s, and then realized that only a few of them would be included into the official premises of the Biennale. In conversations artists agreed that this format could not correspond to a local survey. They however insisted that their primary idea for the Bienniale was to create a space where their artistic achievements would be challenged through the confrontation with artworks of their peers from other places. For them, due to state pressure, this concept had been betrayed, and selection committees would decide according to their views of contemporary art.

This dissatisfaction with the Biennale turned to fury in 2000, when the president of the selection committee, James Elliott, then director of Stockholm's Moderna Museet, and an internationally highly renowned biennial curator, announced during the press conference the end of painting and the dominance of installation art. Sylvain Sankalé, a member of the same committee, writes that after a first selection process only works of installation art had been chosen, and there had to be a re-consideration in order to bring back painting and sculpture (Sankalé 2005: 51).

11 Years later, many artists still refuse this imposition of an art form. They view it as further proof that most of these curator-experts have no knowledge of the history of modern and contemporary African art. Even so, the edition of 2000 was definitely a high point in favouring installation art. 'It appears as unique in the practice of installations among Senegalese artists, and probably among their African homologues, insofar as it seems the privileged technique for participating in the Biennale of Dakar, as if they have to comply to the criteria and conditions of selection imposed by its committees' (Sylla 2008). And Senegalese art historian Abdou Sylla continues to question whether this is 'a fashion or a free choice?' (ibid.). For the 2016 Biennale edition at the Ancien Palais de Justice, the following art forms were on display at the Exposition internationale: twenty-eight artists with installations (various mixed media), twelve using photography, ten painters, eight video artists, and four sculptors. 


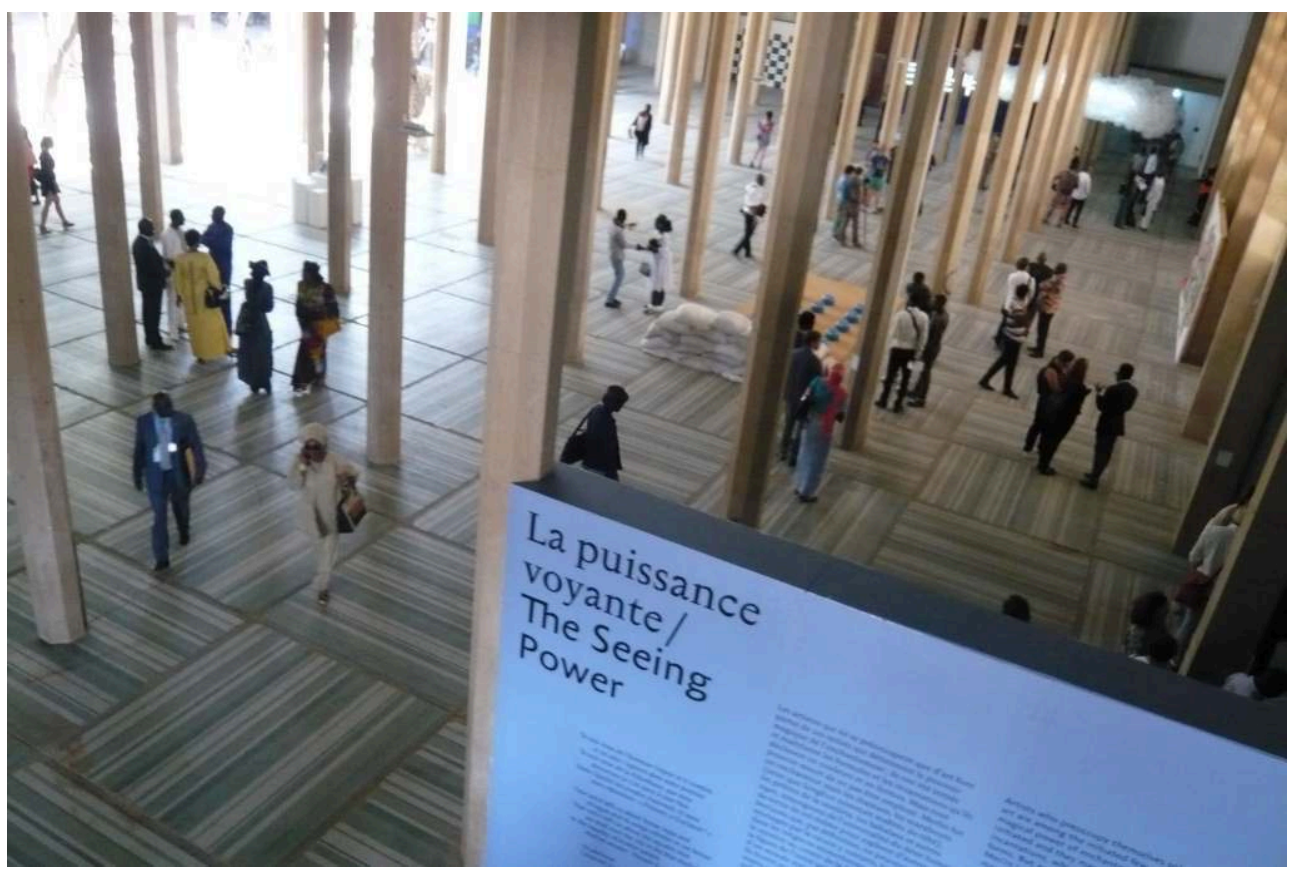

Photograph by Thomas Fillitz

12 These are some reasons for independent artistic activities in the Dak'Art Off space. Its main characteristics are: (a) exhibitions largely use alternative, non-prestigious art sites (restaurants, hotel lobbies, private houses, public places, etc.); (b) there is no overall curatorial activity; (c) there are no selection processes, anybody from where ever may exhibit, suffice to find a space; (d) Off activities stretch out to other regions of Senegal, St. Louis being its second centre; (e) one objective is promoting the sale of artworks.

Exhibitions of Dak'Art Off contrast sharply with the dominance of installation art in the Biennale's central exhibition. Installations are present, no doubt. Yet, whether in individual or group exhibitions, the visitor encounters painting as the dominant art form . In 2012, Clarisse Djionne organized one of the most successful exhibits at Biscuiterie de Médina, an alternative site consisting of several former industrial buildings. She invited four prominent artists, Soly Cissé, Camara Gueye, Ndary Lo, and Cheikhou Ba. Three of them are renowned for their paintings, while Ndary Lo is one of Senegal's most prolific sculptors, and contributed a sculptural installation, Windows part 1 (2012).

14 Walking around off events, two major trajectories regarding art practices may be formulated: (a) paintings, and not installation or participatory art are dominant art forms within Dakar's art world; and (b) the assertion of contemporary art's insertion within social, economic, and political contexts requires some in-depth examination. Both these observations contrast with allegations of global art discourses, that biennials define contemporary art (see Green and Gardner 2016).

One could argue that the orientations of the off are due to the possibilities for sales, given the presence of an international public interested in art. It is the case that most artists exhibiting in the off make their larger income for at least a year, if not for the following two years, but this does not adequately explain the phenomenon. Many insist 
that painting is the art form through which they express their ideas and interests. They refer to the history of modern art in Senegal for understanding the value they attribute to painting, and how they relate to various societal contexts.

\section{The Preponderance of Painting}

\section{Trajectory A - Modern Art, Senghor and State Patronage}

On his accession to the presidency, in 1960 Léopold Sédar Senghor founded the École des Arts du Sénégal from the former Maison des Arts du Mali (1958-59) (Sylla 1998: 85), and in 1979 it was re-named into École Nationale des Beaux Arts. From its beginnings, the art academy was focused on painting, and to a much lesser extent sculpture. In its early days, it was subdivided into two departments; artist Iba N'Diaye directed one following classical European art academy training (Arts Plastiques), while Papa Ibra Tall and Pierre Lods took care of the other focusing on black artistic research (Recherches Plastiques Nègre).

17 As Senegalese art historian Abdou Sylla (1998) notes, more than eighty per cent of artists practiced painting (ibid.: 110). Sculpture was marginal at the school of fine arts. Anne Jean-Bart remarks that it was 'the poor relative of Fine Arts in Senegal' (1989: 145). Sculptural materials and tools were expensive, modern machines were not available on the market, studio space was limited, a sculptor's social status was less distinguished than the one of painters, and Islam rejected sculpture (ibid.: 145; Sylla 1998: 122). One needs to add that Senghor even marginalized the Senegalese souwere painting tradition (verre églomisé painting). He strongly favoured painting as taught by Papa Ibra Tall and Pierre Lods that best corresponded to his ideology of Négritude, and to his vision of the role of artists for a national cultural narrative.

Iba N'Diaye soon resigned and in 1967 he decided to return to France: 'I was aware that the craft is the first thing to learn, it is an obligation, and one cannot economize it. But I met an opposed current. They spoke of spontaneity, of négritude' (Iba N'Diaye 1994: 53). ${ }^{1}$ Clearly, the rejection of any European oriented technical training and of occidental art history, the support of free expression and of the connection to some African culture core made the success of the department of research in black art. Papa Ibra Tall, however, left the school in 1966, when he was appointed director of the newly founded Manufacture Nationale de Tapisserie in Thiès, in the East of Dakar.

Thus, Pierre Lods became most influential. He had joined Dakar's art academy in 1961 at the invitation of Senghor, and stayed until his death in 1988. His ideas of teaching painting relied on his experience with the famous Poto-Poto workshop school in Brazzaville, which he had founded in 1950 and directed until his departure for Dakar. As Amadou Sow reported to me, Lods encouraged his students to observe forms in the natural environment, to interact with African cultural expressions (texts, music, old arts), to trust their intuition, and to pay attention to bright colours and rhythm. If, in the early days' topics were masks, imaginary spirits, rituals, etc. (Ebong 1991: 201), by the end of the 1960s younger artists had shifted towards exploring symbols. Joanna Grabski (2013) designates these artworks of this so-called École de Dakar as 'figurative abstraction' (ibid.: 283). This is an abstraction that several artists I had conversations with referred to styles of old African sculptures to image aesthetic values and 
worldviews. Their concern with this style, indeed, was to reflect how to picture the particular topic they were researching.

Senghor's favouring of this specific form of painting was expressed in the eminent role of the state as patron of the arts, as collector, as financer of artists' residencies abroad, as organizer of exhibitions. In 1966 he founded the Musée Dynamique on Dakar's Corniche Ouest, which would become the centre for Senegal's modern art by the early 1970s, and in 1977 the Cité des Artistes, studios for government sponsored artists in Colobane quarter (Sylla 1998: 81; Harney 2004: 142-3; 146), which would be destroyed under his successor Abdou Diouf in 1983.

Former Musée Dynamique

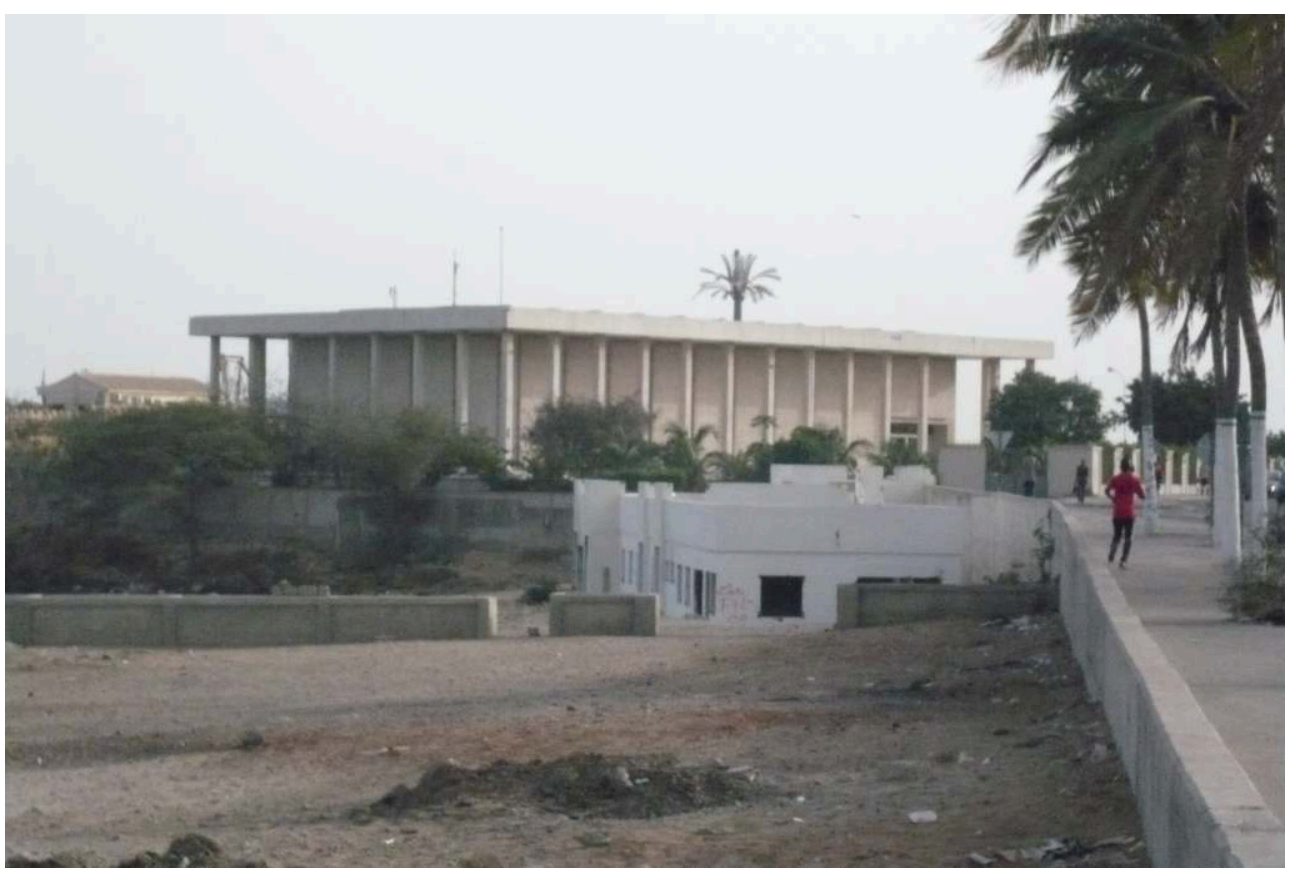

Photograph by Thomas Fillitz

Senghor has further influenced artistic practices and art discourses in Senegal. His initiative for the $1^{\text {er }}$ Festival Mondial des Arts Nègres (First World Festival of Back Arts) in 1966 is well recognised. Old African arts were heralded at the Musée Dynamique, and under the title Tendances et Confrontations (trends and challenges) modern art of African artists and artists of the Diaspora was exhibited at the Palais de Justice on Plateau, Cap Manuel - the grand prize having been awarded to Christian Lattier from Côte d'Ivoire for his rope sculptures which combine modern artistic expression with references to African cultural traditions.

In the early 1970s, Senghor initiates a two-way cultural dialogue with art's modernism. First, within the emerging Dakar art world, several exhibitions of European masters are organized at the Musée Dynamique: in 1971 of Marc Chagall, in 1972 of Pablo Picasso, in 1973 of Pierre Soulages, in 1974 of Friedensreich Hundertwasser, and in 1976 of Alfred Manessier. All are friends of Senghor from his time in Paris, except the Austrian Hundertwasser (see Belting and Buddensieg 2018).

The other initiative is oriented towards international art worlds. On the basis of the success of the first and second Salons of Senegalese artists at the Musée Dynamique 
(1973, and 1973-74; Huchard 1989: 77), Senghor initiates the grand travelling exhibition 'Art Sénégalais d'Aujourd'hui' which starts at the Grand Palais in Paris (1974), and tours in Europe and the Americas until 1982 (Tamsir Niane 1989: 83).

\section{Trajectory B - Ancien Marché Malien and Laboratoire Agit'Art}

One of the most impressive sites of Dak'Art Off 2018 was the group exhibit The Bell of the Ants at the Ancien Marché Malien nearby Place des Tirailleurs and the railway station.

\section{Ancien Marché Malien, Dak'Art Off 2018}

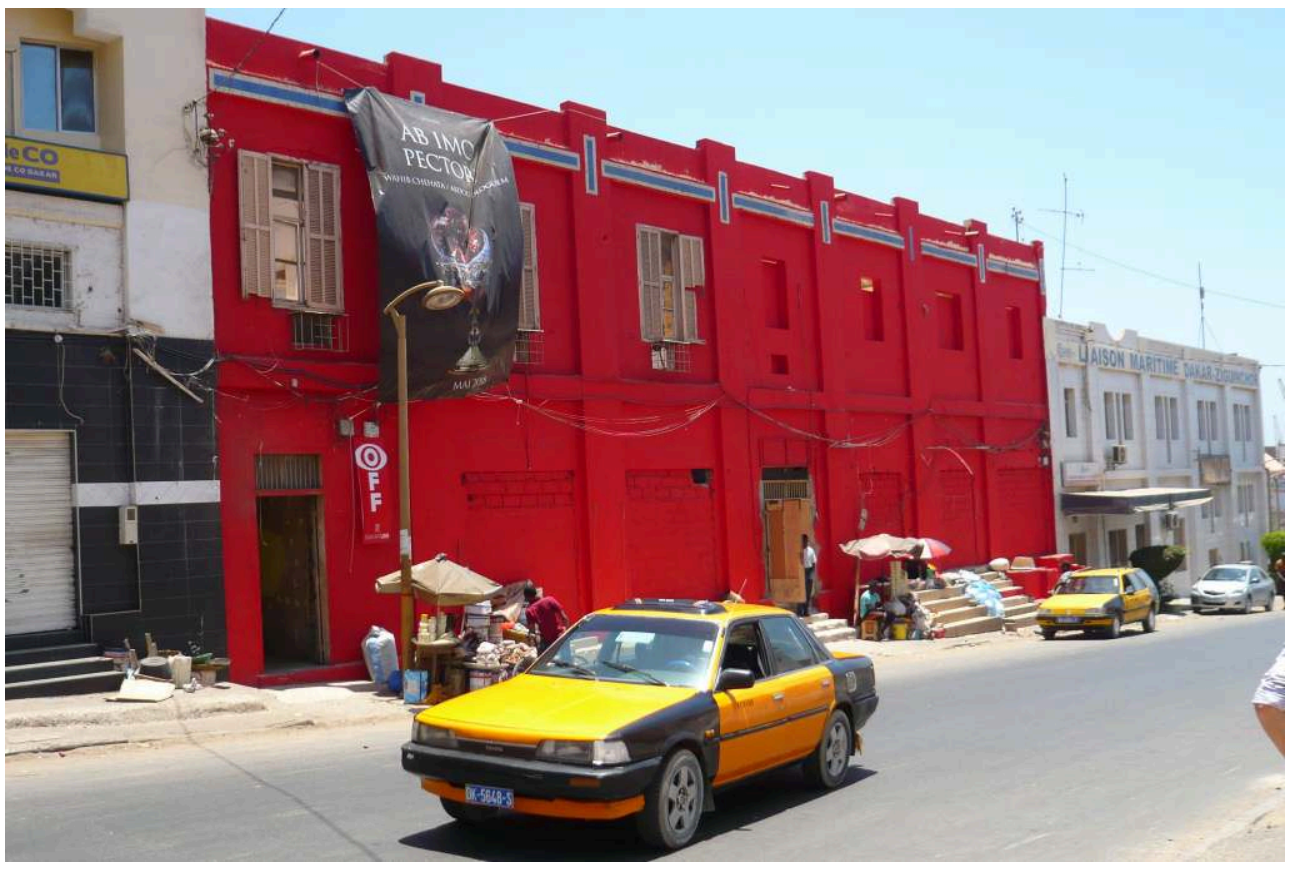

Photograph by Thomas Fillitz

The Collectif Agit'Art had adapted the demolition building, and one would walk around in deep sand, paintings and photographs are hanging on dilapidated walls and illuminated by ready-installed spotlights, and tarpaulins are used as ceilings. Young artists of revitalized Laboratoire Agit'Art (e.g. Ndoye Douts, Claire Lamarque, Pascal Nampémanla Traoré), with invited international (e.g. Maïmouna Guerresi, Jems Koko Bi, Younes Baba Ali) and Senegalese ones (e.g. Soly Cissé, Kémi Bassène, Wasis Diop) have contributed paintings, photographs, sculptures, multi-media installations, films, and graffiti. Paintings, however, are preponderant.

In a central space, the visitor encounters an installation of Claire Lamarque, Joe Ouakam et son Bras-O-Bab (2017), a life-size representation of most influential artist and art theorist Joe Ouakam, holding in his right hand a bundle of red ropes stretching out on the walls and towards the sculpture of a baobab in the form of a majestic hand that reaches the ceiling. 
Claire Lamarque, Joe Ouakam et son Bras-O-Bab (2017).

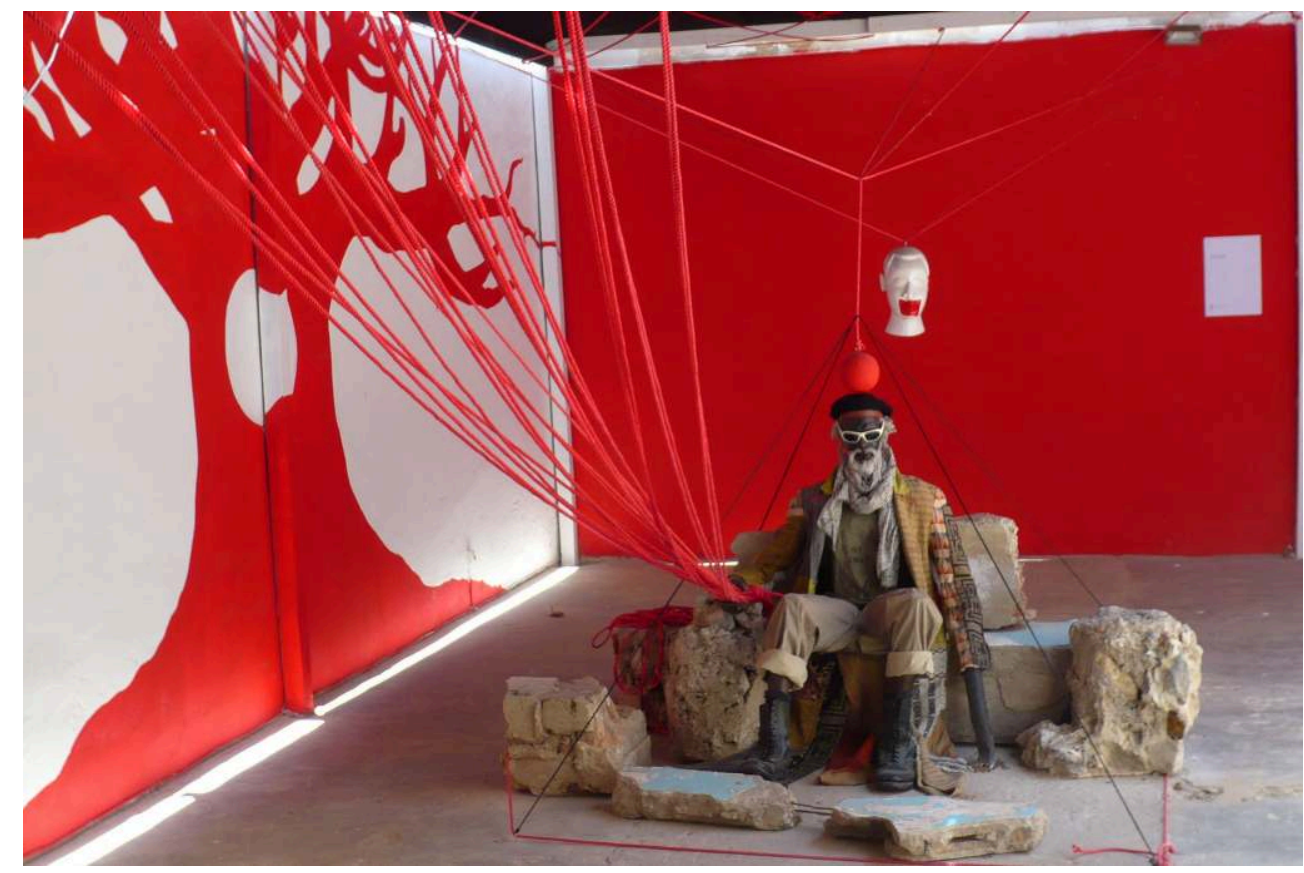

Dak'Art Off 2018

Photograph by Thomas Fillitz

27 Again, Joe Ouakam is remembered in the large courtyard with Jems Koko Bi's sculpture Les enfants de mille nuits (the children of one thousand nights; 2018), and with graffiti texts on the walls - not as a commemoration, but to invigorate Agit'Art's ideas and activities for the present-day young Laboratoire generation (Ba 2018: 22)

On a Sunday morning, the Collectif Laboratoire Agit'Art holds a meeting. Former companions of Joe Ouakam report on their encounter with this outstanding personality in Dakar's art world, and his conceptualization of art and society. At the end of the meeting the Collectif presents its Dismemberment Manifesto (2018). 'Through our collaborative practices, we aim to destroy the current diktats of contemporary art. Our collective actions are forms of resistance against the dominant system but also a critique of political and cultural institutions that intent to dominate us' (Nampémanla Traoré 2018: 1). 


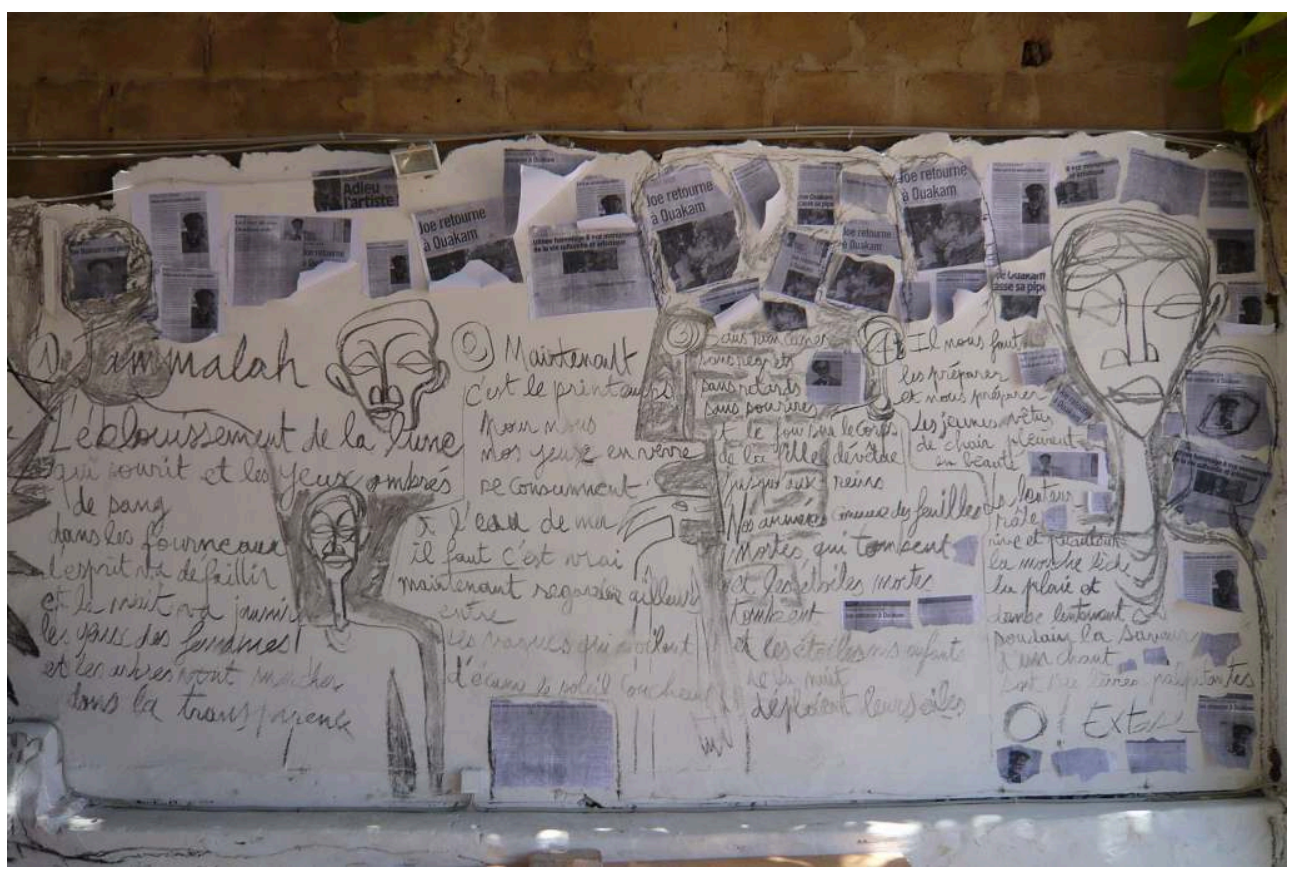

CAPTION= Dak'Art Off 2018

Photograph by Thomas Fillitz

Ancien Marché Malien 'radiates the spirit of Joe Ouakam,' remarks Ousseynou Wade, former Secretary General of the Biennale, in a conversation during the Sunday meeting. It is an alternative site in ruins, not a prestigious art space, and was consciously selected for its popular connotation. This is the artistic trajectory that was launched in 1973 with the foundation of Laboratoire Agit'Art by, in particular, Issa Samb/Joe Ouakam (visual artist, art theorist), Jibril Diop Mambéty (filmmaker), Youssoupha Dione (playwright, performance artist), and many others who rapidly joined in. It was a fundamental critique of the artists of the École de Dakar, who considered their artistic practices as non-political while these latter claimed their agency for a national cultural narrative around Négritude. For Agit'Art, the École de Dakar 'allows itself to be used by the reigning political current '(Samb 1989: 118).

For Laboratoire Agit'Art, the figurative abstraction of artists in the tradition of the École de Dakar, although connected to styles of old African art, was detached from societal concerns, and inappropriate to cope with Senegal's political and economic crises of the early 1970s. According to Ima Ebong (1991), these artists 'were generally unable to reflect on or to adjust to social and political change' (ibid.: 204). Hence, Laboratoire Agit'Art conceived its practices outside the system of state patronage, rejected this modernist style, and opted for art activism: 'If art is a kind of developer, ... art itself should be a place for revealing the diversity of truth' (Samb 1989: 130). It was founded on the collaboration of artists from different art fields, and combined various visual art forms, such as performance, installation, painting, and sculpture. Furthermore, Agit'Art introduced heterogeneous materials, piles of newspapers, books, documents, objects of everyday life, etc. In order to insert art within the societal environment, its works were project oriented with an emphasis on ideas and concepts. 'Dismemberment' was central for the operational structure of the movement, and for avoiding institutionalization: a group of initiates coordinated the overall structure, 
while each activity, a workshop or a performance, was organized as separate entity (Harney 2004: 109-10).

La cour de Joe Ouakam in 2010

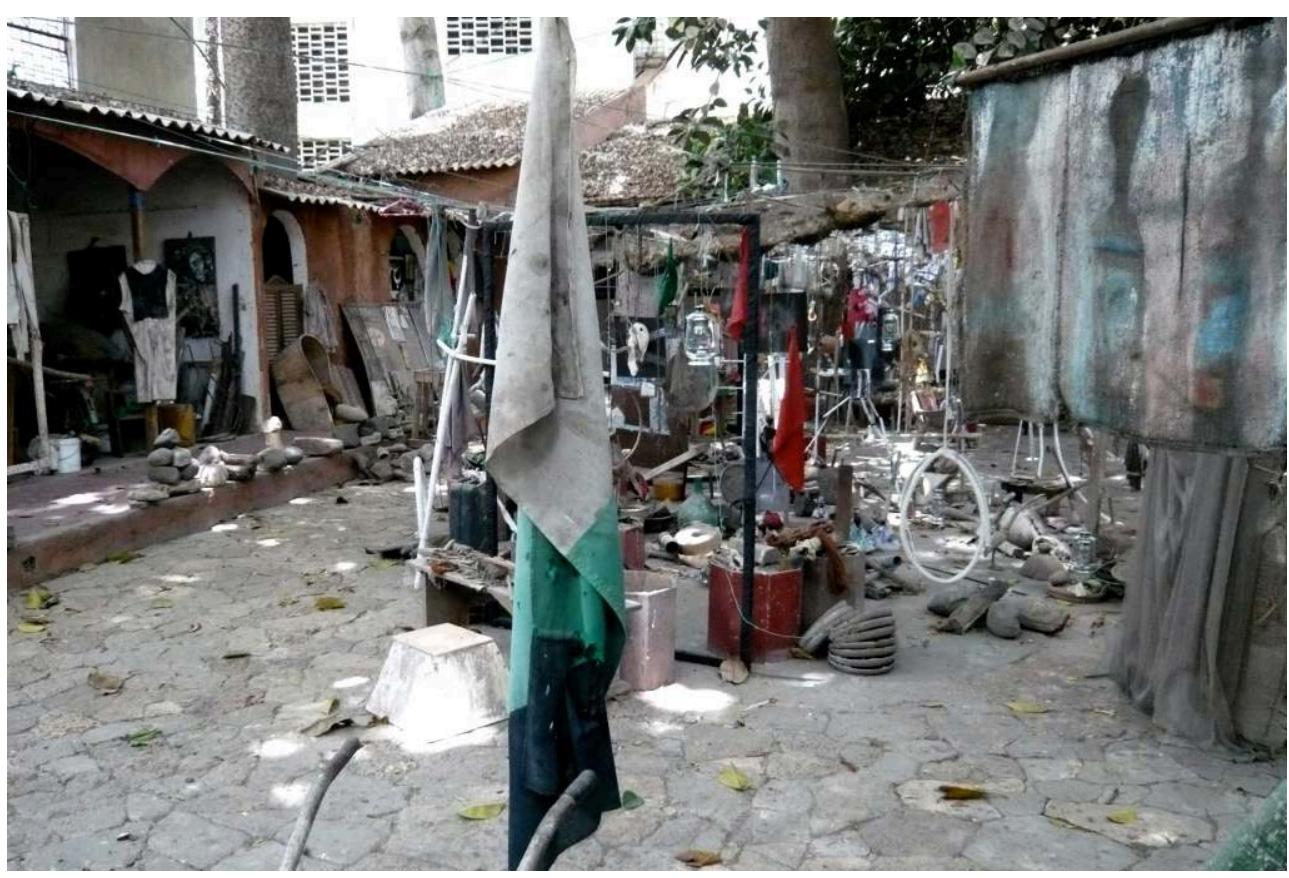

Photograph by Thomas Fillitz

31 From 1973 to 1977, Agit'Art was located in Joe Ouakam's courtyard on Plateau, from 1977-1983 it had joined the Village des Arts, and afterwards returned at Joe Ouakam's place at 17, rue Jules Ferry. La cour de Joe Ouakam, as it was known in Dakar's art world, was not only a centre for artistic encounters and debates, it was an artwork in permanent progress, open day and night to people, until it was razed to the ground after the artist's death in 2017.

\section{In Between: The Reformulation of Painting: The Village des Arts and Sét Sétal}

Mansour Ciss Kanakassy presented an installation in the official Senegalese pavilion of Dak'Art 2018, of which he dedicated one part to the memory of the former Village des Arts (1977-83). The artist had arranged pictures of the artists villageois, of encounters and events that had taken place on the site, copies of documents and narratives (e.g. 'L'ancien "village des arts" de Dakar' by El Hadji Sy), and a list of all resident artists. The Village des Arts had become an emblem of the rise of contemporary art in Senegal.

In 1977, El Hadji Sy in search of a studio squatted spaces of the former military camp Lat-Dior, near Corniche Ouest, and founded the Village des Arts. Until 1976, some of the barracks were home to the École Nationale des Arts, later re-named École Nationale des Beaux Arts until 1982 (Kalidou Sy 1989: 36; Harney 2004: 141). Other artists rapidly followed. Like the Cité des Artistes, Senghor's initiative for government sponsored artists, the Village des Arts was cleared violently on the order of President Abdou Diouf in late 1983 (Harney 2004: 143). The Village des Arts, however, was in sharp contrast to the Cité des Artistes. The government neither sponsored the Village, nor would it 
influence or control its activities. Apart from studios, the site incorporated a theatre and a music studio, and exhibitions, encounters, conferences and workshops were organized both for artists and the interested public.

Since the early 1970s Senghor's politics had been facing political opposition, against his one-party system, or his close interaction with France, and economy was in growing turbulence. While honouring Senghor for his dedication to culture and the arts, many artists, including Souleymane Keïta, liberated themselves from the state sponsored canon for painting. A vast diversity of artistic practices ensued (see Sylla 2008), pushing research on the means of painting. These developments moreover coincided with the exhibitions of European masters which Senghor had initiated at Musée Dynamique from the early 1970s .

El Hadji Sy was another leading personality in these endeavours. Although he was in close contact with Pierre Lods, and admired him (El Hadji Sy 1995: 88), he maintained distance from the state's interference in the arts, and broke with the artistic framework of the École de Dakar (Harney 2004: 126), that is with the absolute prioritization of figurative abstraction, the marginalization of sculpture as well as of the traditional souwere artistic practices.

The Village des Arts became a symbol for a close interaction and exchange between the resident artists and their various practices, for intensified research in the arts, and a search to narrow the connections to neighbouring inhabitants. To these ends, artists started to incorporate alternative materials and to try out new techniques, be it in painting or in sculpture (Harney 2004: 142). Wood and jute are experimented instead of canvases, while found objects would provide paintings with a three dimensional volume.

In 1980, El Hadji Sy founded the gallery Tenq ${ }^{2}$ in his studio (Harney 2004.), as a joint location without any restrictions for artistic practices. Hence, the Village, the gallery Tenq, and the search of alternative artistic practices correlated with Laboratoire Agit'Art's conception for intensified artistic insertion into societal environments, and for an art freed of imposed conventions. But while Agit'Art understood itself as an activist art movement, and was from its inception combining various art forms in its projects, artists in the Village des Arts did not constitute an art movement per se. They worked as individuals, although in communication with their surrounding peers, predominantly in painting and sculpture, and aimed at going beyond Senegal's modernist conventions of style, materials, and techniques.

The economic crisis of 1980, particularly the imposition the first structural adjustment plan, was another impetus for furthering the artists' récupération of everyday materials, insofar as brushes, canvases, oil and acrylic colours had either become expensive or could hardly be found on the market. Further, the artistic intention to reach local communities via the récupération of everyday materials gained another impetus in 1990 with the Sét Sétal ${ }^{3}$ movement in Dakar. This was a movement of local youth who started to clean Dakar's quarters from the waste that was all around. Rapidly, artists joined the movement, and created murals with all kinds of topics, or small artworks in neighbourhoods out of waste materials. ${ }^{4}$ Sét Sétal thus stimulated a second artistic process of récupération, which has nothing to do with scarcity of artistic materials, or with an opposition to the dictate of artistic conventions in Senghorian times. It is above all an interest in the quality of the material for creating an artwork. But one should not consider this as a common intentional process. Viyé Diba, for instance, is interested in 
urban materials, in the research of their qualities. His topic is the urban environment, and the artist himself defines the three-dimensionality of his paintings as style kangourou. In contrast, sculptor Moustapha Dimé recuperated what the sea was throwing on the shores of Gorée Island, where he had installed himself, and was interested in traditional African cultural meanings. Even so, artists I had conversations with insist that the technique of récupération is not uniquely a process of appropriating waste or other materials (e.g. sand, textiles, ropes, metal plates, plastic). These practices require knowledge of their qualities, of how to handle them technically, how to assemble different materials in order to create meaningful works of art.

\section{The Off and Contemporary Painting Practices}

This short sketch of the history of modern painting in Senegal should not be read as a linear narrative of superceding art styles. From 1960 on, painting indeed has been the prevailing art form, and had developed in multiple directions by the early 1970s: in relationship to ideas, styles, materials, techniques, and in one strand, searches for inserting art into societal concerns.

Visits to Dak'Art Off events clearly provide insights to these various trajectories. At the (second) Village des Arts adjacent to the Léopold Sédar Senghor football stadium, which was inaugurated in 1983 under President Abdou Diouf, the Off group-exhibitions of its residents may be traced to figurative abstraction of the 1970s, but without recalling traditional African symbols.

Themes relate to present-day matters. In 2016, art historian Roselie van Deursen curated the small off-exhibition Urban Africans: les artistes briseurs de tabou (Urban Africans: taboo breaker artists) at the residency of the Dutch ambassador. Kine Aw was one of the artists of the show. She graduated from the École Nationale des Beaux Arts in 2006, and has her studio at Village des Arts. The artist's themes are women, their cultural traditions and their present-day social issues. Kine Aw works on the proportions of bodily parts, distorts them, and collapses perspectives within each picture. 
Painting by Kine Aw.

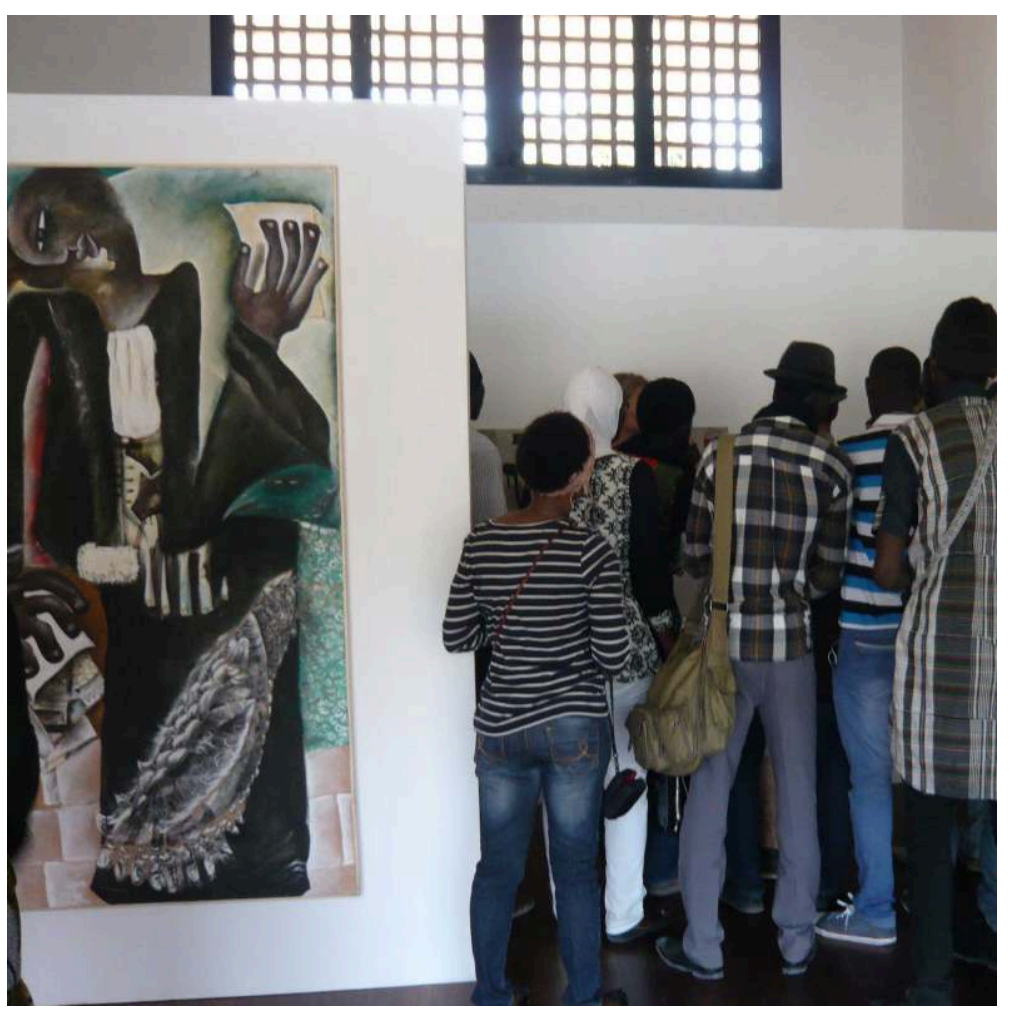

Exhibition Urban Africans: les artistes briseurs de tabou. Dak'Art Off 2016.

Photograph by Thomas Fillitz

The German Goethe Institute contributed to the 2014 Off with an exhibition of young autodidact Fally Sene Sow. He re-defines the old souwere (sous-verre) tradition, which artists of the former Village des Arts had brought back into modern painting practices in the late 1970s. In creating pictures of the Colobane market area, his overall subject, the artist works centrally with recuperated materials from the local environment. Fally Sene Sow practices sous-verre collages, applies sand, cuts out aluminium strips from soft-drink cans, images from magazines, other found materials, and combines them with painting. These filigree assemblages of materials require the artist to protect the back of the pictures with transparent plastic plates. 


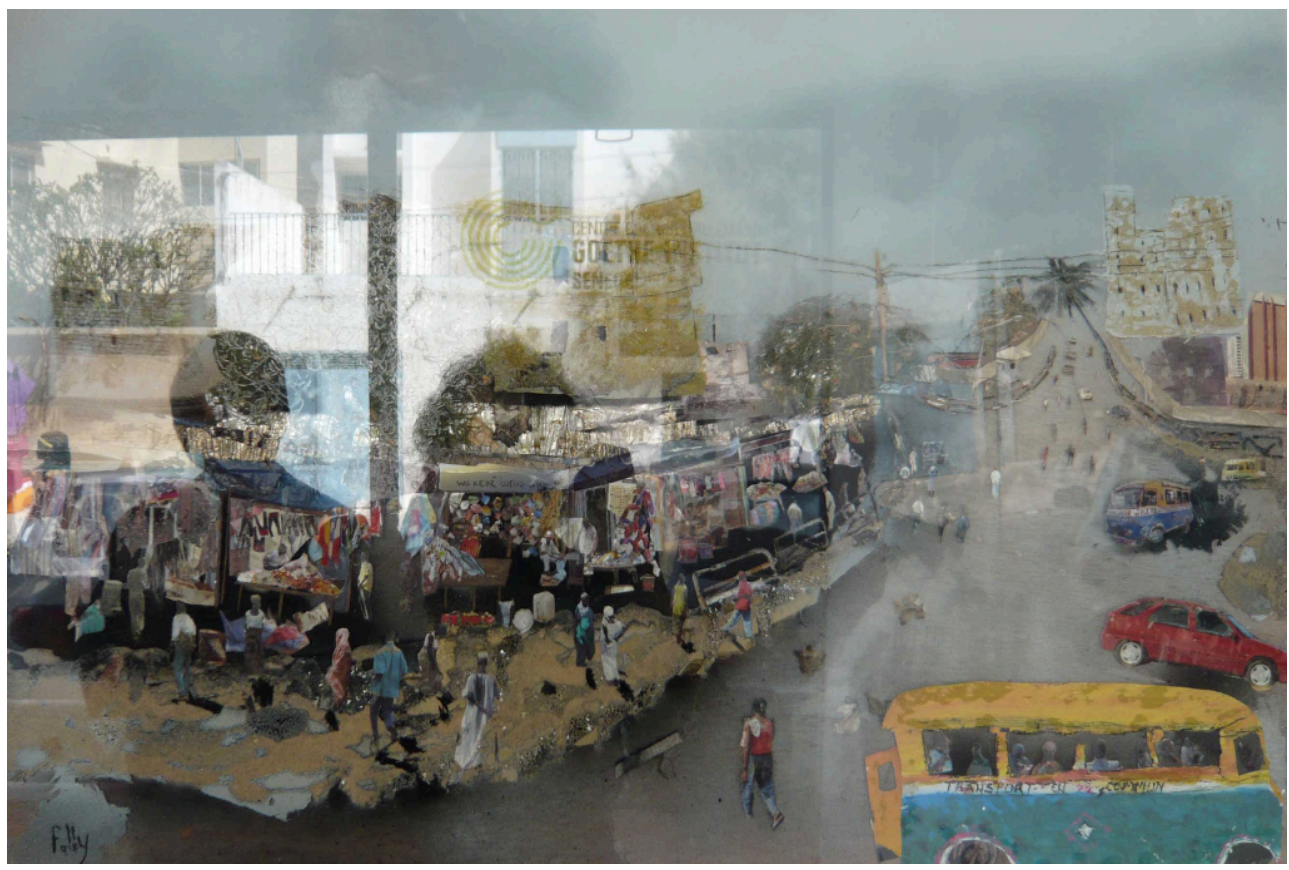

Dak'Art Off 2014.

Photograph by Thomas Fillitz.

43 At the northern end of Bay of Mermoz, with the commanding monument Renaissance Africaine on the horizon, Barkinado Bocoum has rented a friend's villa for his off 2018 exhibition. A characteristic of his technique immediately leaps out: the artist subdivides the plane of his pictures into demarcated fields nested within one another, and elaborates each field meticulously. Between these fields, the artist deconstructs the representation of faces, of human bodies, and objects. When speaking of his paintings, Barkinado Bocoum views each of them as an image of interconnected changes of perspectives. It is, however, not research on perspective in painting - indeed the artist questions the various facets of human beings in social interactions and emotional expressions, what is made visible, what remains hidden, or what is yet not revealed to others. Likewise, for Barkinado, any social phenomenon consists of an amalgam of differently situated gazes, and not in one exclusive viewpoint. In his 2018 exhibit, the artist consequently expands his focus on the relationship between the personality of individuals, consumption, and the impact of adverts, as in the cycle A force de copier l'autrui on déteint son "voyez-moi » \# 3 (2018; By dint of copying the other one bleaches one's 'see me' \#3). 
Barkinado Bocoum, A force de copier l'autrui on déteint son « voyez-moi » \# 3, 2018

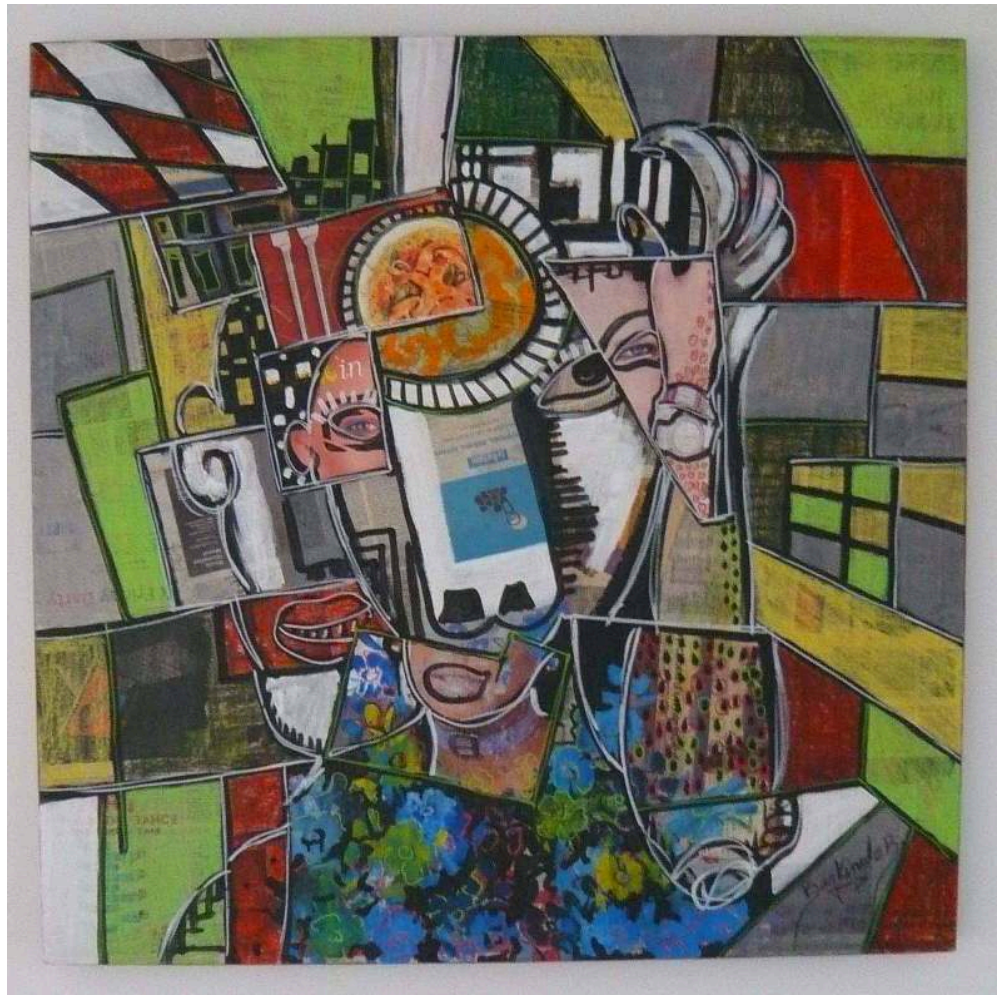

Dak'Art Off 2018

Photograph by Thomas Fillitz

The multiple sides of human beings are also the driving idea of Cheikhou Ba's artistic creations. He graduated first in Dakar in 2002, later in Geneva in 2011, lived for several years in Geneva and Neuchâtel, and resettled in Dakar in 2016. For the Off 2016 at Hôtel Villa Racine on Plateau, the artist presented a project at the invitation of the Spanish curator Jesús Ahedo of Kalao Panafrican Creations, Bilbao: Hommage à Rafael Padilla CHOCOLAT de son nom d'artiste 1er clown noir de la scène française 1868-1917. ${ }^{5}$ 


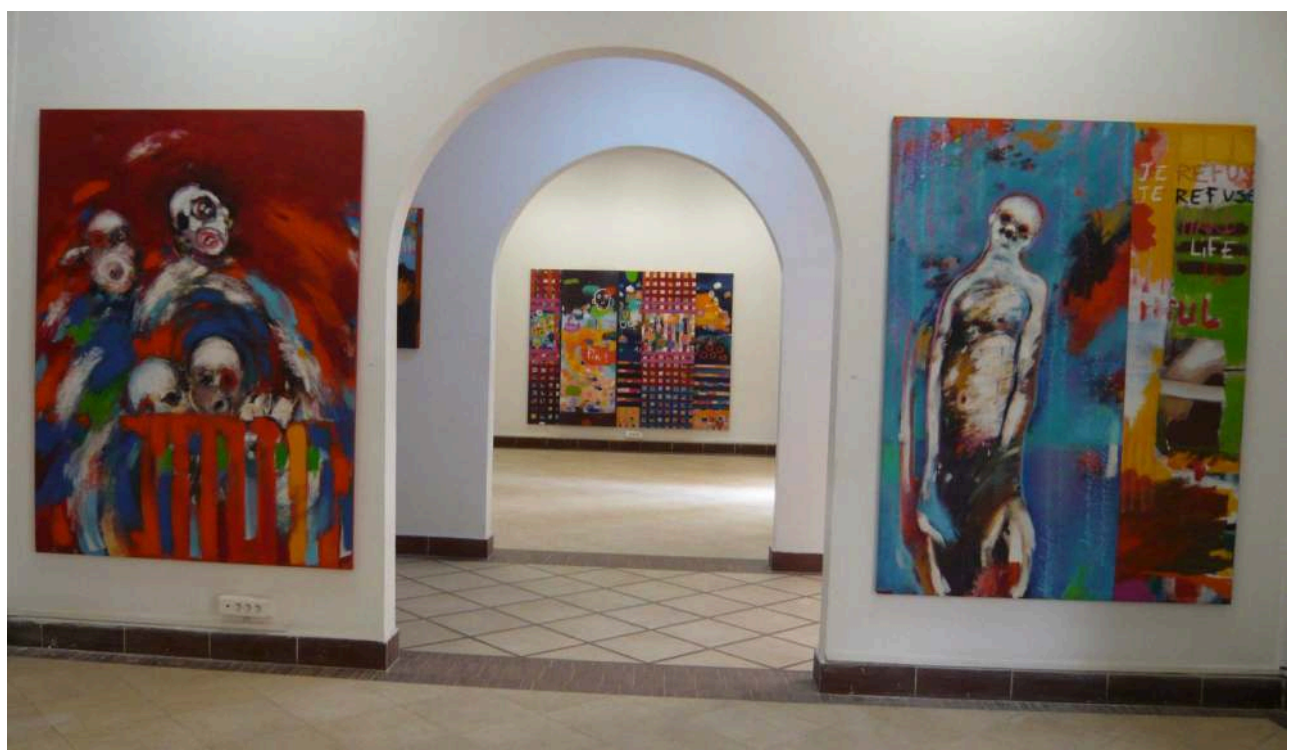

Dak'Art Off 2016.

Photograph by Thomas Fillitz

With these artworks, Cheikhou Ba honours an artist who had long passed into oblivion. To capture different aspects of Padilla's career, and in keeping with his style around these years, the artist works the canvasses with stains of bright colours, his brush strokes move in all directions, faces and bodies are fuzzy, and he includes here and there graffiti-like word tags.

At Hôtel Sokhamon, facing the îles de la Madeleine, Viyé Diba presents a highly interesting re-conceptualization of painting in Galerie Kemboury's exhibition Lignes partagées (shared lines) during the Off 2016. At a first glance, the visitor sees strange forms. They however rapidly unravel as paper collages of roughly designed, cut out, and assembled bodily forms. These artworks are the outcomes of the artist's thoughts and feelings following the news of the terrorist massacres in Paris on November 13 2015. For this oeuvre, the artist partly relies on the two-dimensional painting format, with grey coloured paper as support, frame and glass. Viyé Diba, however goes further, and constructs three-dimensional constellations of pictures that are hanging in the space. Mounted on frames of wildly tied cables, violently worked fine white nets are used as support. Hence, the frame, the support, and the assemblage, all forcefully edited, as well as the hanging become integral to the experience of these spatial pictures. The perception of the beholder is further challenged as $s /$ he moves around and in-between them, thus changing with each position the gaze on these pictures. 
Viyé Diba. Exhibition Lignes partagées (2016), detail

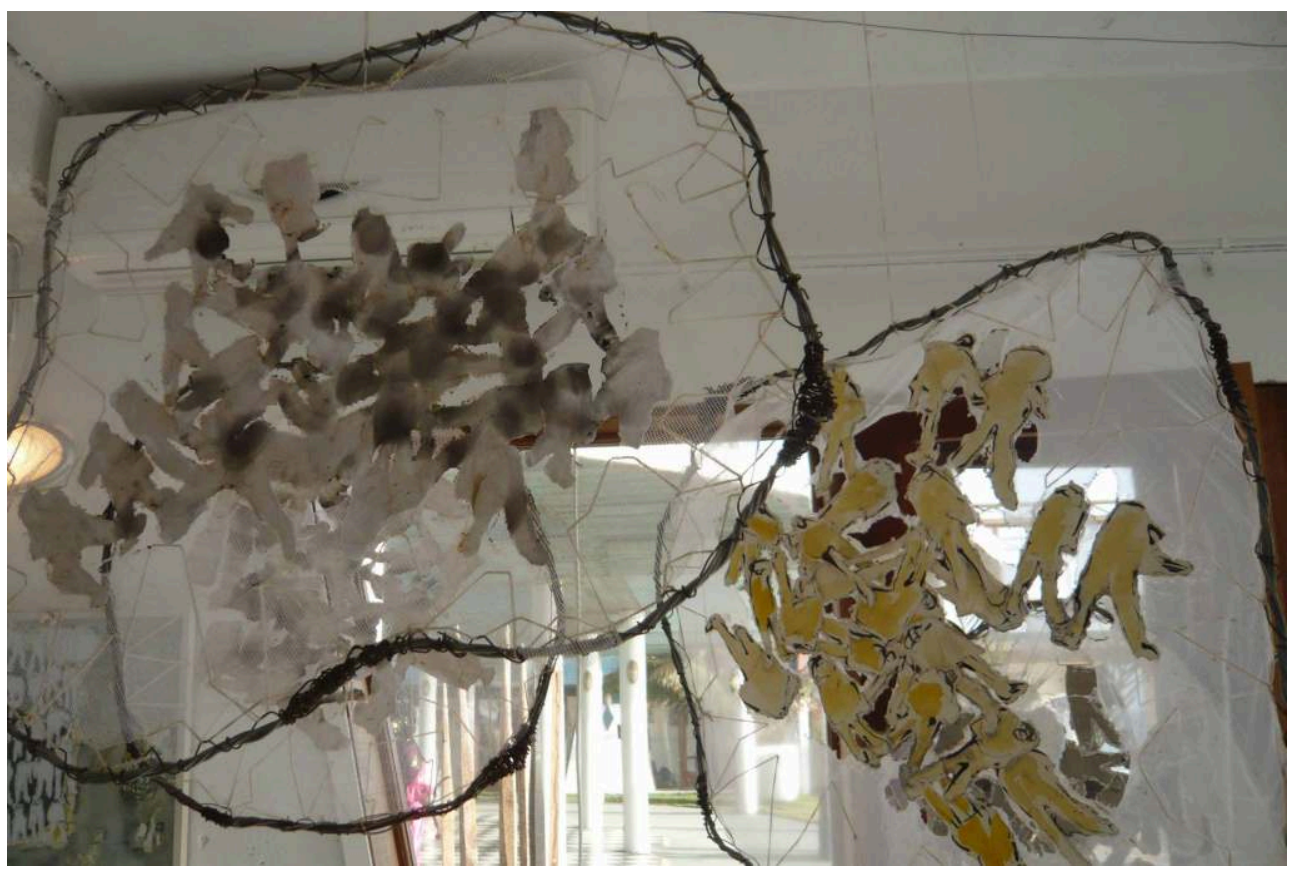

DAK'ART OFF 2016.

Photograph by Thomas Fillitz

\section{The Off, a Contemporary Art Canon, and Art's Social Aspirations}

In Contemporary Curating (2012), Terry Smith reports of a roundtable on exhibition curating in Africa chaired by Chika Okeke Agulu, in which participants argued that biennials are art-events in which curators visualize pressing contemporary issues by means of the art forms they conceive as most relevant (ibid.: 153). Simon Njami, an internationally prestigious curator of contemporary African art, and artistic director of Dak'Art 2016 and 2018, also asserts in conversation that a biennial's objective is not a kind of monographic display of artistic achievements from a local art world. Nevertheless, the notion of 'biennial art,' and the production of another (global) contemporary art canon stand as critiques of dominant global art discourses, and stimulate to examine the relationship between local contemporary artistic practices and major art biennials' favouring of dominant art forms: (a) installation and participatory art, and (b) a socially engaging art.

In this context, the informal field of Dak'Art Off imposes itself for investigation. Although installation and performance art have increased also in this field since the Biennale's edition of 2000, painting remains the dominant art form, and not only for market sales reasons as the short historical sketch shows. Since the beginning of modern art in Senegal, painting has been the art form par excellence, first strongly favoured by Senghor's cultural politics, and in art education. This art form, however, was periodically re-conceptualized, be it regarding styles, the materials used, the tools and the techniques. A major line of these reconfigurations requires to be considered out of local discourses and exchanges. The international exhibitions at Musée 
Dynamique, which Senghor enabled between 1971 and 1976, constitute a first impact for artist-painters to extend beyond the limits of the early École de Dakar style - away from the exclusive figurative abstraction, towards a symbol and colour centred, nonfigurative abstraction. Besides residencies of artists in Europe and North America, the Biennale of Dakar further influences painting practices, in particular with a move towards the mixing of styles as exemplified in the artworks of the younger generation of artists (e.g. Barkinado Bocoum, Cheikhou Ba).

In global art discourses, the important aspect of contemporary art, however, is its insertion in societal issues (e.g. Rancière 2001, Smith 2011, García Canclini 2014), and the preferential display of such art forms in mega-art events by leading internationally acting curators (e.g. Enwezor, Hanru, Christov-Bakargiev). This shift articulates the contrast to occidental art history's modernism, for which art's changes were characterized by the artists' reflections within art's autonomous practices (styles, art forms, materials, techniques). Contemporary art as an 'art of the world' (Smith 2011: 8; italics by the author) emphasizes the societal connections, and correlates such art practices with installation art and more so with participatory art - the former incorporating everyday objects into art's field, the latter centring on the re-production of social relations, and rejecting art as material good. At the Biennale of Dakar, this move can be observed with the preferential selection of installation art which deals with ICT and other objects of present-day urban life (cf. Sylla 2008).

In Senegal, however, the autonomy of modern art does not correspond to occidental art history's meaning. To a large extent, it always had some connection to societal fields. From the 1960s on, art students were trained to first conceive a topic in relation to their environment which then would be researched by means of the tools of art (painting, etc.). The topics indeed would change in time, as well as the conceptualization of art's insertion into society. Further, during his presidency, Senghor attributed artists the role of important agents for the production of the national cultural discourse (Grabski 2013: 288-9). Their concern was the idea of an African cultural core, and they reflected this in their picture-making with traditional African cultural symbols. As much as these pictures corresponded to the objectives of the independent state, and to Senghor's ideology of Négritude, they nevertheless had but little to do with people's concerns in urban environments. These artworks became symbols of the state's cultural politics, while critics emphasized the abandonment of art's critical potential.

51 A trajectory towards art's autonomy in European modernism's sense starts by the late 1960 and early 1970s, with a diversification of art forms, and the detachment from the early École de Dakar, from its stylistic and thematic constraints, and from the role of the artists as agents of the national cultural narrative. In this strand, the creation of pictures is highly individual and stylistically diversified. Even so, main common denominators are the primacy of the artistic research on the grounds of art's tools for expression, and a move towards non-figurative abstraction.

52 At the same period, another trajectory opens up with those peers, who are searching for ways to narrow the relationship between art and society by elaborating and strengthening art's critical potential. Laboratoire Agit'Art takes the lead, elaborates the combination of various art forms, and takes counter-positions to political power. One needs to acknowledge that the artistic practices of Agit'Art correspond to present-day global art discourses about art's insertion into society. 
53 From the mid-1970s on, painting's concerns about its relationship to society may be connected to both trajectories, to the liberation of artistic practices from the constraints of a national cultural discourse, and to the activities of Agit'Art. Hence two artistic strategies became preponderant for this art form: firstly, the focus on urban social themes, and second the inclusion of everyday materials from local environments (récupérations): in the early 1980s with the enforcement of the first structural adjustment plan which implied scarcity of the materials for painting. In 1990, the Sét Sétal social movement constituted another impetus, and artists actively developed the incorporation of objects and materials of everyday life. This entailed a re-formulation of painting, from its two dimensionality into a three dimensionality, and the development of new techniques with the application or assemblage of different materials. Further, while artworks were exhibited in spaces of art, artists also intervened in local neighbourhoods.

54 Painting at the service of contemporary social aspirations continues to be an objective of Senegalese artists in the present: the situation of women, facets of one's personality in modernity, plural perspectives on social, economic or political facts, the importance of social relations as against individualization, obstacles to transnational mobility, migration flows, etc. Artistic practices draw on the freedom of stylistic expression, and thereby connect to local developments of the late 1970s, or to a mixing of styles with intensified international exchanges. Nevertheless, these artworks require art related visual skills from its audience. Although artists take inspirations from local issues, their pictures are often highly sophisticated elaborations, as a major objective is their research in the possibilities of the picture's expression. Thus, while their topics deal with people's aspirations, local neighbourhoods can hardly cope with these pictures, as they are not trained in these forms of artistic practices.

Senegal's history of modern and contemporary painting thus unravels some central aspects for art's objective to insert itself into society. Topics of societal aspirations are not sufficient, the question is how an image reflected by the artist encounters as picture the public. This relates to the combination of styles, techniques, and materials, to the spaces where these artworks are incorporated in - art spaces, or alternative popular ones -, and which target groups the artists envision. This brings us back to the Collectif Agit'Art at Ancien Marché Malien during Dak'Art Off 2018. With this exhibition, the Collectif questions the possibilities of art forms as critical medium for social aspirations and as mediator for social interactions. 


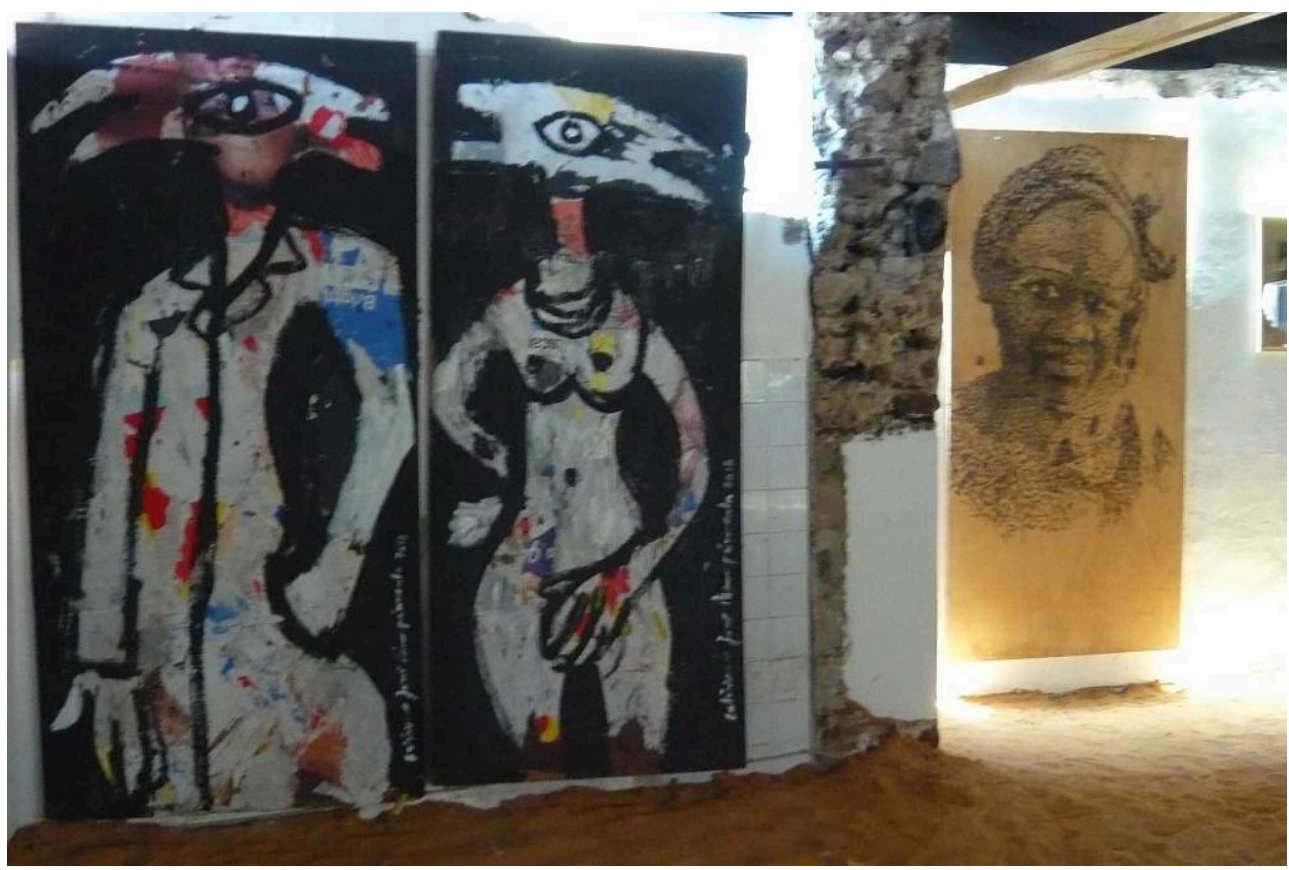

Dak'Art Off 2018.

Photograph by Thomas Fillitz

Asking what art's insertion into society can mean, its exhibition focuses on how an artwork can reach the people who are concerned. The project clearly positions itself in opposition to elitist exhibition practices: by settling in a public environment (the former Marché Malien), in a building in ruins, it aims at narrowing the accessibility of artworks for a general public. Through the display of various art forms, and in particular of different kinds of paintings, it also encourages to reflect artistic issues how an artwork can reach people beyond an art instructed audience.

\section{Conclusion}

Curators and other art experts agree that biennials are not local surveys of artistic achievements, but global in scale. Due to the tremendous proliferation of this exhibition format in the 1990s and early 2000s, they view an emerging homogenization, a 'biennial art': similar global topics, similar structures of the exhibits, selections around a core group of preferential artists, and of a few dominant art forms. Some art theorists therefore assume that this leads towards another global art canon, no longer defined by occidental art history, but by the curators' preferential tastes of an art that is embedded in society. While in the past biennials were seen as terrains of free experimentation, this assumption implies that these mega-events and their concomitant global art discourses determine artistic practices in local art worlds which is the central question of this article.

While Dakar's Biennale of Contemporary African Art started with the objective to display the newest achievements of artists of Africa and its diaspora, the impact of global art discourses on selection procedures and invitations of artists can be observed rapidly, particularly visualized through the growing importance of installation art 
using new technologies. Dakar art world professionals struggle with this trajectory of the Biennale's exhibits. On the one hand, they welcome such an internationalization infused by curatorial decisions, but they also wonder, on the other, about the representation of local artistic practices. In other words, they feel uneasy as to whether the Biennale is already overly inscribed within hegemonic global art discourses.

This tension marks the success of Dak'Art Off. What is conceived as the popular part of the Biennale may be expressed with the following key ideas: no overall curatorial narrative, diversity of artistic practices, freedom of exhibiting, and alternative, non-art dedicated sites. Hence, the visitor who strolls around the Off encounters multiple forms of painting. Some may be connected to different periods of the history of modern art in Senegal, others are expressions of a deeper exchange with the art of the official Biennale spaces. Social aspirations are a common denominator of all these artworks, however artists elaborate a huge diversity of themes, at various degrees of intensity, and in their individual practices.

In an overall perspective, Dak'Art Off's exhibitions offer an image of demarcation from global art discourses and their aesthetic judgements about the most relevant art forms and pressing issues. Indeed, Dakar's artists and art world professionals see it in opposition to the official Biennale. Nonetheless, the relationship between both spaces rather appears as a complementary one - as exchanges between international art world strategies, a geospatial plurality of art practices, and local artistic intentions. This thrillingly relationship reorients our investigation to the entanglements of specific biennial exhibitions with local histories of art practices and discourses, and in the context of Dakar the off stands for its antinomy to another hegemonic global contemporary art canon.

Groys, Boris. 2008. The Topology of Contemporary Art. In Antinomies in Art and Culture. Modernity, Postmodernity, Contemporaneity. Terry Smith, Okwui Enwezor, and Nancy Condee, eds. Pp. 71-80. Durham and London: Duke University Press.

\section{BIBLIOGRAPHY}

\section{Books and articles}

Ba, Abdou. 2018. No title. In Le Manifeste du Démembrement/The Dismemberment Manifesto. Laboratoire Agit'Art, ed., editorial direction Abdou Ba with Delphine Calmettes. Pp. 17-22. Dakar: Bathie Sow.

Belting, Hans and Andrea Buddensieg. 2018. Ein Afrikaner in Paris. Léopold Sédar Senghor und die Zukunft der Moderne. Munich: C. H. Beck.

Ebong, Ima. 1991. Negritude: Between Mask and Flag - Senegalese Cultural Ideology and the "École de Dakar". In Africa Explores. $20^{\text {th }}$ Century African Art. Susan Vogel, ed., assisted by Ima Ebong. Pp. 198-209. New York and Munich: The Center for African Art and Prestel. 
García Canclini, Néstor. 2014. Art Beyond Itself. Anthropology for Society without a Storyline, trans. David Frye. Durham and London: Duke University Press.

Grabski, Joanna. 2013. The École des Arts and Exhibitionary Platforms in Postindependence Senegal. In A Companion to Modern African Art. Gitti Salami and Monica Blackmun Visonà, eds. Pp. 276-293. Malden, MA. and Oxford: Wiley Blackwell.

Green, Charles and Anthony Gardner. 2016. Biennials, Triennials, and documenta: The Exhibitions that Created Contemporary Art. Malden, MA. and Oxford: Wiley Blackwell.

Harney, Elizabeth. 2004. In Senghor's Shadow. Art, Politics, and the Avant-Garde in Senegal. 1960 - 1995. Durham and London: Duke University Press.

Huchard, Ousmane Sow. 1989. The Salons of Senegalese Artists. In Bildende Kunst der Gegenwart in Senegal/Anthologie des Arts Plastiques Contemporains au Sénégal/ Anthopology of Contemporary Fine Arts in Senegal. Friedrich Axt and El Hadji Moussa Babacar Sy, eds. Pp. 77-78. Frankfort/Main: Museum für Völkerkunde.

Jean-Bart, Anne. 1989. Sculpture. In Bildende Kunst der Gegenwart in Senegal/Anthologie des Arts Plastiques Contemporains au Sénégal/ Anthopology of Contemporary Fine Arts in Senegal. Friedrich Axt and El Hadji Moussa Babacar Sy, eds. Pp. 145-146. Frankfort/Main: Museum für Völkerkunde.

Nampémanla Traoré, Pascal. 2018. No title. In Le Manifeste du Démembrement/The Dismemberment Manifesto. Laboratoire Agit'Art, ed., editorial direction Abdou Ba with Delphine Calmettes. Pp. 1-2. Dakar: Bathie Sow.

N’Diaye, Iba. 1994. Iba N'Diaye s'entretient avec Franz Kaiser. In Peindre est se souvenir. Iba N'Diaye. Pp. 52-54. Dakar: NEAS - Sépia.

Osborne, Peter. 2013. Anywhere or not at All. Philosophy of Contemporary Art. London and New York: Verso.

Papastergiadis, Nikos. 2008. Spatial Aesthetics: Rethinking Contemporary Art. In Antinomies in Art and Culture. Modernity, Postmodernity, Contemporaneity. Terry Smith, Okwui Enwezor, and Nancy Condee, eds. Pp. 363-381. Durham and London: Duke University Press.

Rancière, Jacques. 2001. Le partage du sensible. Paris: La Fabrique-éditions.

Samb, Issa. 1989. The Social and Economic Situation of the Artists of the "Ecole de Dakar". In Bildende Kunst der Gegenwart in Senegal/Anthologie des Arts Plastiques Contemporains au Sénégal/ Anthopology of Contemporary Fine Arts in Senegal. Friedrich Axt and El Hadji Moussa Babacar Sy, eds. Pp. 117-120. Frankfort/Main: Museum für Völkerkunde.

Sankalé, Sylvain. 2005. Some Magical Sparks in many Trivialities?. Afrik’Arts 2: 50-51.

Smith, Terry. 2011. Contemporary Art-World Currents. London: Lawrence King Publishing.

Smith, Terry. 2012. Thinking Contemporary Curating. ICI Perspectives in Curating No. 1. New York. Independent Curators International.

Sy, El Hadji. 1995. Objects of Performance. A Story from Senegal. In Seven Stories. About Modern Art in Africa. Clementine Deliss, ed. Pp. 76-101. London, Paris-New York: Whitechapel, Flammarion.

Sy, Kalidou. 1989. The School of Fine Arts of Senegal. In Bildende Kunst der Gegenwart in Senegal/ Anthologie des Arts Plastiques Contemporains au Sénégal/ Anthopology of Contemporary Fine Arts in Senegal. Friedrich Axt and El Hadji Moussa Babacar Sy, eds. Pp. 35-40. Frankfort/Main: Museum für Völkerkunde. 
Sylla, Abdou. 1998. Arts Plastiques et Etat au Sénégal: Trente Cinq Ans de Mécénat au Sénégal. Dakar: IFAN-Ch. A. Diop.

Tamsir Niane, Djibril. 1989. The Exhibitions of Senegalese Contemporary Art Abroad. In Bildende Kunst der Gegenwart in Senegal/Anthologie des Arts Plastiques Contemporains au Sénégal/Anthopology of Contemporary Fine Arts in Senegal. Friedrich Axt and El Hadji Moussa Babacar Sy, eds. Pp. 83-84. Frankfort/Main: Museum für Völkerkunde.

Verwoert, Jan. 2010. The Curious Case of Biennial Art. In The Biennial Reader'. Elena Filipovic, Marieke van Hal, Solveig Øvstebø, eds. Pp. 184-197. Bergen and Ostfildern: Bergen Kunsthall and Hatje Cantz.

\section{Websites}

Sylla, Abdou. 2008. Les Arts Plastiques Sénégalais Contemporains. Ethiopiques 80. Available online: http://ethiopiques.refer.sn/spip.php?page=imprimer-article\&id_article=1599 (accessed 29 August, 2016).

\section{NOTES}

1. 'Je savais que le metier était la première chose à apprendre, que c'était une obligation dont on ne pouvait pas faire l'économie. Mais j'ai rencontré un courant opposé. On parlait de la spontanéité, de la négritude.' (My translation).

2. Wolof: joint, connection; see Samb 1989: 118.

3. Wolof: Cleaning up, being clean.

4. Ndary Lo's sculptural installation Windows part 1 (2012) at Biscuiterie de Médina during Dak'Art Off 2012, may be considered in line with this tradition.

5. 'Hommage to Rafael Padilla CHOCOLAT from his artist name $1^{\text {st }}$ black clown on the French stage', an exhibition enabled by the Embassy of Spain in Senegal.

\section{ABSTRACTS}

Critical considerations of the impact of biennials on artistic practices worldwide emphasize that they create new hegemonies: biennials produce another canon of contemporary art at a global scale. The main characteristic is art's insertion into society, with the primacy of installation and participatory art forms.

This article examines these assumptions in considering the art shown in the field of Dak'Art Off, an initiative of Dakar's artists in opposition to the Biennale's main venue, the Exposition internationale. Whereas installation art is preponderant in this latter space, exhibitions in the off show largely paintings. To understand this discrepancy, one needs to view the history of modern art after Senegal's independence. Furthermore, contemporary art's characteristic of its insertion into society requires a differentiated analysis for this art world, as this aspect has been an objective throughout the history of modern and contemporary art in Senegal, though with changing meanings, artistic practices, and targeted public. 
Des études critiques sur les biennales considèrent qu'elles créent aujourd'hui de nouvelles hégémonies dans le domaine des pratiques artistiques: elles produisent un autre canon d'art contemporain à l'échelle globale, qui induit l'insertion de l'art dans la société, et la primauté de l'installation et de l'art participatif.

Cet article examine ces suppositions à partir de l'art exposé dans le champ de Dak'Art Off, initiative des artistes Dakarois, développée en opposition aux manifestations officielles de la Biennale, l'Exposition internationale. Pendant que les installations sont prépondérantes dans ce dernier espace, les expositions du off montrent plus largement des peintures. Pour comprendre cette divergence, il faut surtout considérer l'histoire de l'art moderne depuis l'indépendance du Sénégal. De plus, le critère des aspirations sociales de l'art contemporain requiert une analyse différentiée dans cet univers de l'art, vu que cet aspect fut un objectif principal tout au long de l'histoire de l'art moderne et contemporain au Sénégal - bien que son sens changeât, ainsi que les pratiques artistiques et le public ciblé.

Las consideraciones críticas acerca del impacto de las bienales en las prácticas artísticas alrededor del mundo subrayan que éstas crean nuevas hegemonías: las bienales producen otro canon de arte contemporáneo a escala global. Su característica principal es la inserción del arte en la sociedad, dando primacía a la instalación y a las formas de arte participativo.

Este artículo examina estos supuestos tomando en consideración el arte mostrado en el ámbito de Dak'Art Off, una iniciativa de artistas de Dakar que nace en oposición al evento principal de la Bienal, la Exposition internationale. Mientras que en este último espacio las instalaciones son preponderantes, las exhibiciones en off muestran principalmente pinturas. Para entender esta discrepancia es necesario ver la historia del arte moderno después de la independencia de Senegal. Además, las aspiraciones de inserción social del arte contemporáneo requiere un análisis diferenciado para este "mundo del arte", ya que este aspecto ha sido un objetivo a lo largo de la historia del arte moderno y contemporáneo en Senegal, aunque con significados, prácticas y públicos cambiantes.

\section{INDEX}

Mots-clés: Biennales, Dak'Art, art de biennale, monde de l'art de Dakar, aspirations sociales de l'art.

Palabras claves: Bienales, Dak'Art, arte de bienal, mundo del'arte di Dakar, aspiraciones sociales del'arte.

Keywords: Biennials, Dak'Art, biennial art, Dakar art world, art's social aspirations

\section{AUTHOR}

\section{THOMAS FILLITZ}

Dept. of Social and Cultural Anthropology, University of Vienna

thomas.fillitz@univie.ac.at 